\title{
Ancient View of Psychological Contract in Gurukula
}

\author{
Ramcahandra G Killedar, S .C. Patil
}

\begin{abstract}
The Ancient Indian education system was mainly residential that was Gurukula system of education. Guru used to teach all the skills and knowledge to his student. He used to except the some unspoken obligations and behavior from his students as of his own son's/daughter's behavior. Both the Guru and student used live together and learn together. After the completion of the course students used to pay honorarium Guru Dakshina. Guru used to put his students in many difficult situations and ask him to act and respond. Guru used to share all his experiences and care for his students he used to love his students when ever required he used to punish his students. Guru used to except good behavior, feeling of respect, feeling of importance, attention, love, care and loyal relation with his student throughout the life. On other hand student used to see his hero in his master, he should be skillful, intelligent, knowledgeable, should give love, affection, no partiality and should give blessings or boon to the students Guru was everything to him. The relation was like father and son/daughter and the education was perfect. There was no financial relationship between them. Student used to except Guru should solve their all problems and make them tension free and give the remedial solutions for their problems in life. It was sacred relationship between Guru and student like God and Bhakta. The development of psychological contract is based on emotional communication. If there is a miss-conceptualization of perceptions and communication, It will also affects on the attitude and behavior of Guru and students. When there is a breach of psychological contract it is going to affects the society at large.
\end{abstract}

Keywords: miss-conceptualization of perceptions and communication, honorarium Guru, knowledgeable.

\section{INTRODUCTION}

India is the mother land of all philosophical subjects and paradise of gaining and distributing of knowledge and Gurus were considered as God. Guru means Big, teaching was not mere preaching, It was a holy work whatever they need to teach they need to follow the values, ethics, truth, honesty, social responsibility, social issues, character development, gaining self control and confidence. Guru used to get utmost respect and considered as spiritual and intellectual father. Every kingdom used to have their Kula-Guru (may be today's Vice Chancellors) for making better decisions and taking advice for every development of the kingdom In ancient India, Gurukul was the system of education where Guru and student used to live in the same house. And we Indians believe "Still you become a slave of Guru you would not get salvation." Without a guru no education is possible. Ancient guru he himself was an walking institution, living University and an Alma matter.

Revised Manuscript Received on August 13, 2020.

* Correspondence Author

Ramcahandra G Killedar*, Research Scholar, Rani Channamma University, Belagavi, Director at College of Business Administration, People Education Society, Ugar Khurd, Belagavi, Karnataka, India.

Dr. S .C. Patil. Chairman, Department of Management Studies, Rani Channamma University, Belagavi, Karnataka, India.

(C) The Authors. Published by Blue Eyes Intelligence Engineering and Sciences Publication (BEIESP). This is an open access article under the CC BY-NC-ND license (http://creativecommons.org/licenses/by-nc-nd/4.0/)
Guru was to lead the student from the darkness of ignorance to the light of knowledge this was only possible with the parental care of Guru. There was very personal relationship between student and Guru. Warm and friendly relationship was maintained between both. There was no financial relationship between Guru and student. Teaching was very noblest profession and it was a sort of social obligation Guru was having every right to refuse the student if he is not qualified to receive the education. The transmission of knowledge was possible only through instrumentality of Guru. Guru used to test the every student's aptitude and enthusiasm in the particular discipline. Every ancient Guru was an ideal and moral person and of high character.

One of the most ancient Gurukula know in Indian history was in Mahabharat Dronacharya's Gurukula (5200 years old ) which was called as Guru's village Gur-gaoan went on to become today's Gurgoan, near New-Delhi.

Guru is to give life to the student and guide him for the art of well living, Guru was friend, philosopher and guide, Guru used to transform his knowledge orally, there were no printed text book the teaching in ancient India was not regarded means for livelihood. The relationship between Guru and student was regarded as father to son or daughter. Guru used to keep a guard over the conduct of the student, to prevent him from his offences students used to have deep respect towards Guru, students has to walk after his Guru, he has to get up early in the morning to salute his Guru by touching his feet. Students never used to contradict with his Guru. Student must not have to take the higher seat in-front of his Guru. Student has to do the duties of the son towards Guru, student has to wash all the utensils, washing cloth of teachers, gazing the cattle, bringing wood fuel for cooking, and he has to beg for his master. Simple living and high thinking was the mantra of ancient Indian education system. Students after the completion of regular course also, students used to meet his master for any advice throughout their life. It was lifelong relationship,it was ever ending. Guru used to mould the personality of the student, the student used to have devotion at his Guru worshiping as his God. In ancient India education was perfect and complete.

Social psychology: The origin of psychological contract is from social contract. It means relationship between individual the state or society \& the individual in what he turned the "Social Contract". Social Contract got developed by understanding social psychology. The meaning of Social Psychology is the "scientific study of how people influence each other's thoughts, feelings \& behaviors in a society". We are also often influenced by our culture, national standard, Advertising \& social expectations.

Blue Eyes Intelligence Engineering

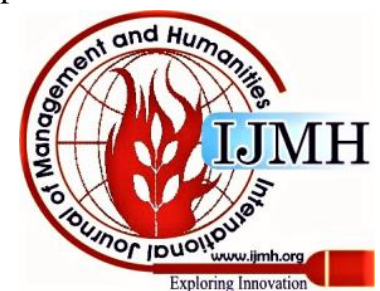




\section{Ancient View of Psychological Contract in Gurukula}

Social Psychology plays very important role on development of Psychological Contract.

Psychological contract : If we see the perceived history of Psychological Contract (seen in 3000 BC) it has been assumed that people used to get Psychological Contract with their God. People used to perform their obligations and used to ask the God to perform his obligations in reverse. People used to pray, offer everything to God and in return they used to demand to fulfill their own desires. Psychological Contract is a kind of invisible contract between employers \& employees (or any two parties where they come together to work or to live together) Psychological Contract, a special contract form, were formed based on the emotional communications and reached an invisible agreement about rights behavior and obligations. We can define Psychological Contract is the set of 'Promises' or 'Expectations' that are exchanged between the parties in an employment relationship. And it is unwritten set of expectations between the employee \& employer. It includes informal arrangements, mutual beliefs, common ground \& perceptions between two parties. There is one contract that is not signed that is Psychological Contract.

\section{DISCUSSION}

Psychological Contract of Guru Vs Student: Indian social psychology towards Guru during the ancient period it was totally different, Gurus were everything for the students. Guru used to never work for salary, teaching and inspiring was their way of life. We believe Guru Brahma, Gurur Vishnu, Gururdevo Maheswara.... That is the Guru is creator, protector and destroyer. The meaning of Guru is big. And the biggest planet in solar system is Guru. Guru used to remove ignorance and take the student towards salvation. Students used to leave their house and stay at Gurukulas and used to beg for their food and clean the whole Gurukula campus and they were like slaves to the master. Master was unquestionable by the students and the society. People used to worship Gurus. If we see the great Indian epic Mahabharata the relationship of Dronacharya and Ekalvya, the student Ekalvya was ready to scarify anything to his master, when his master asked him to give his right thumb finger he did not give second thought for the master's order he took knife and surrendered his right thumb finger to his master. That was the psychological contract of Guru vs student. And the eldest son of Kunti, a great warrior Karna who was eager to get the warfare from great master Dronacharya. But Dronacharya refused and rejected for the reason that you are not born in the religion of Kshatriya and you are not a son of King, so I will not preach you the Dhanurvidya or warfare. Then Karna went towards another great master Parashuram and lied saying that he belongs to the family of Brahmin and wants to get the Dhanurvidya and his master allowed him to stay at his Gurukula. Parashurama used to teach only Brahmins, as he was having revenge attitude towards Kshatriyas. One fine day, when the master was taking rest on the lap of his student Karna. Lord Indra came in the form of Bee, in order to benefit his son Arjuna and bee stung Karna's thigh, but Karna did not move as he did not want to disturb his guru. When Parashuram woke up and saw the blood coming out from Karna's wound he instantly finds out Karna is not a Brahmin. Because Brahmins are not so strong and they are unable to bear the pain. Here the psychological contract of Guru breaches, students should never lie and he doesn't wanted to take Kshatriyas as his student. So Enraged Parashuram curse him that he would forget all his knowledge when it is essentially required. This curse came into effect in Kurukshetra war when he was fighting against Arjuna, so Karna forgets the mantra to invoke Brahmastra against Arjuna on the battlefield .This tells us if there is a breach of psychological contract then there will great adverse effect of the parties.

At the Gurukula of Sandipani muni lord Krishna and his brother Balarama along with Sudhama they studied many subjects and they were very dear and favorite to the Guru and Gurumata, they all were very close with their Guru and with all their friends. Their psychological contract was very strong and good. On the other hand Drupada and Dronacharya were studying at the Gurukula of Bharadwaj, who was the father of Drona. Drupada and Drone become very close friends and completed their education in Gurukula. After the completion of their education Drupada became king of Panchal where as Drona remained poor Brahmin, during their education Drupada promised Drona to help out during his bad times. After long time Drona could not afford milk to his son Ashwathama, then Drona thought to seek help from his childhood friend King Drupada. But Drupada could not recognize his childhood friend because of his ego and richness. He denied that how can a poor Brahmin could be his childhood friend and he showed the way out to the Drona. Drona got angry and took oath to take revenge on Drupada. Here the psychological contact gets breached and both the close friends become strong enemy.

In the holy book of Jainism "Vaddharadhane" which means worshiping of old age people and Gurus. There is one story of Agnibhooti and Vayubhooti who were son of minister. Both the brothers got addicted to many bad habits and were not having any responsibility, and they were good for nothing. After the death of their father they were called by the king to test their knowledge, but the king felt very bad because, they were uneducated and unskilled to take up the job of their father. So they were rejected and sent back home. Agnibhooti and Vayubhooti's mother Kashyapi tells them to go to the Ashrama of Suryamitra who was the brother of Kashyapi. Kashyapi wrote a letter to Suryamitra to teach her children about Politics, Economics and other skills to run the kingdom smoothly. When both brothers went Suryamitra Ashrama after walking miles together, Suryamitra read the letter and tells to both the brothers that I don't have any sister by name Kashyapi and I am not your maternal uncle. Both the brothers Agnibhooti and Vayubhooti were about to turn to their native place Suryamitra tells them any way you have come from long distance for the sake of education, if you are so much interested you can stay back at Ashrama and you have to do all Chores of Asharama. And you have to beg for your bread and butter. And the good food has to be kept for their Guru, leftover food has to be taken by them. Both the brothers agreed for the conditions.

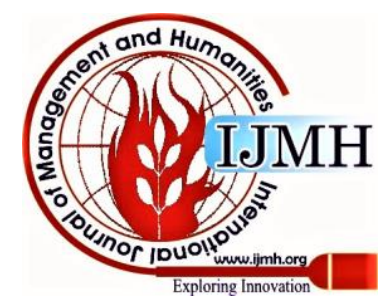


And they completed their education with lot of pain and trouble, many times they slept with hungry stomach. After the completion of their education, on the final convocationday when they were returning to their native Guru Suryamitra tells that I am your maternal uncle, If I would have disclosed this reality earlier you both would have taken me as granted and both would not have taken your education properly. Guru Suryamitra's psychological contract was, students have to face the challenges of life on their own ,if they fail also they have to try again and again. During the time of education Guru should not show love and affection to their students. If Guru become emotional with any student then Guru can't teach properly. Guru has to make them to understand value of food, value of time, value of money and value of people. Student has to accept everything in positive way and they have to come up with flying colours. This was Suryamitra's attitude and Psychological Contract towards his students. But both brothers attitude and Psychological Contract was different.

Agnibhoothi was having good attitude so his Psychological Contract was positive towards his master, whatever the things we have been experienced are the stepping stones for the development for our life. He accepted it as blessings. Where as Vayubhooti took it in negative way and unfavorable Psychological Contract towards his master.He felt that, not a single day our maternal uncle showed any love and affection towards us and never gave good food never spoke with us properly he purposefully tortured us. Guru Suryamitra enjoyed by troubling us. Vayubhooti carried this psychological contact with him. And both the brothers returned to their kingdom and the King tested their knowledge and skills both were well versed with all skills required to run the kingdom smoothly. King felt very happy and appointed them as ministers. After long time,their old master Suryamitra comes to meet his students Agnibhooti and Vayubhooti. Agnibhooti offers lot of hospitality, renders flowers, fruits and wealth and worship his master Suryamitra. And he convey that, because of your teaching and preaching I have reached to the success of pinnacle. Whereas Vayubhooti insults and scolds his master. And shouts that you have created lot of problems for us, being our maternal uncle you didn't show any courteous towards us, you are not good master, purposefully you have tortured us. You didn't teach anything to me, I have learnt everything on my own. I never considered you as my master, You are my enemy, I never respect you and he kicks his master from his Palace. So in ancient time also the Psychological Contract of students were different from student to student.

In the era of Sharana Sahitya (12th century ) Allam Prabhu who was mystic-saint, a great Vachana poet called Vachanakara who was also the President of Anubhava Mantapa, has forecasted the relation of Teachers and Students for generations to come, is as follows,

"In the Kritayuga, If the guru beat and taught wisdom to the pupil. I said it was great grace,

In the Tretayuga, If the guru scolded and taught wisdom to the pupil. I said it was great grace.

In the Dwaparayuga, If the guru frightened and taught wisdom to the pupil. I said it was great grace.

In the Kaliyuga, If the guru bowed and taught wisdom to the pupil. I said it was great grace." Guheshwara.

And Kabirdas explains his own psychological contract towards Guru," If Guru and God (Govinda) comes simultaneously, whom to salute first?" Kabirdas explains," I should salute to the Guru, Because Guru who guided me to the God.

\section{III.RESULTS}

In the view of psychological contract Guru is treasure of experience, knowledge, discipline and he influences the student's eternity. So the student worship the Guru. If there is no Psychological Breach of Contract between teacher and student then there will be very cordial relationship, whatever the Guru or teacher teaches to the student it remains in the hearts of every student. And the student never forgets whatever the Guru has preached to him. Then Guru can alter the attitude of every student. And every student can achieve whatever they want to achieve. This will lead to the Gateway of Innovation, Creativity, Success and Brings harmony in the society. Which will leads to the development of the nation and finally this will make better place to live.

\section{IV.CONCLUSION}

The primary concern of this paper is to show that the concept of the psychological contract also applies to ancient Gurukulas. The unwritten contract existed in the Gurukula as it does in present day industry. If the psychological contract is being met and fulfilled, then there will be an improvement in the quality of education and educational climate. Then there will be more psychic energy will be released for teaching and learning. Guru affects eternity nobody knows where is his influence stops. Therefore many students used to have positive Psychological contract towards their Guru. Guru's Psychological contract affects student's achievement if psychological contract breaches then there will be adverse affect on the student. It is universally accepted that, if any individual or any student wants to be competitive one, then he should have cordia human relations with his Guru and classmates the same philosophy applies for every organization or institute also. This is how the Psychological contract of guru and student went on changing time to time.

\section{REFERENCE}

1. Vaddaradhane by Shivakotiacharya is the earliest extant prose work in Kannada. It is a didactic work consisting of nineteen stories and is based on Harisena's Brhatkathakosa.

2. Psychological contract in employment edited by Denise.M.Roussean/Rene Schalk

3. https://www.google.com/search?q=ancient+gurukul+system\&oq=anci ent + Gurukul\&aqs=chrome.1.016.20255j1j8\&sourceid $=$ chrome\&ie $=U$ TF-8

4. https://en.wikipedia.org/wiki/Vaddaradhane

5. https://www.google.com/search?q=dronacharya+and+eklavya+story\& oq=dronacharya + and + eklavya $+\& a q s=$ chrome.1.69i57j0l5.15802j0j7 \&sourceid=chrome\&ie=UTF-8

6. https://en.wikipedia.org/wiki/Sandipani

7. https://vachana.sanchaya.net/vachanakaaras/3\#myModal_16

8. https://www.google.com/search?q=saptrishi\&oq=saptrishi\&aqs=chro me..69i57j0l5.9920j0j7\&sourceid=chrome\&ie=UTF-8 